\title{
緑化法面における散布種子と周辺植生との関係
}

\section{小向真人 $\left.{ }^{*} 1\right) \cdot$ 福永健司 2)}

1）東京農業大学大学院農学研究科

2）東京農業大学地域環境科学部

摘要 : 近年, 植生管理を前提とする遅速緑化が注目を受けている が, 緑化法面における種子散布の知見は少ない。そこで植生管理 の基礎データとして, 緑化法面における散布種子と周辺植生との 関係を調査した。その結果, 法面の上部と下部とを比較すると, 散布種子数, 種数ともに法面上部の方が多かった。このことから, 法面下部は上部と比較して, 樹木の生育は良好であるが, 種子の 侵入機会が少ないことが確認された。

キーワード : 緑化法面, 散布種子, 植生管理, 周辺植生

\section{1. はじめに}

近年の法面緑化には, 土砂流出防備や防災機能に加えて周 辺景観との調和や生物多様性に配慮することが求められるた め 6)，木本植物を中心とした播種工が主体となっている。特 に，森林が国土の約 7 割を占めるわが国において，防災，景 観および生物多様性に配慮する上で, 木本植物による進行遷 移を手助けすることが求められる。

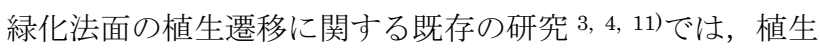
調査により法面の遷移が考察されており, 切土法面において 法面上部は自然植生に接していることが多く，種子の侵入機 会が多いことから遷移のスピードが速いといわれている。植 生管理を視野に入れた種子の侵入に関する研究は，人工林に おいて見られる 1,2,8)。しかし, 緑化法面における種子散布量 の知見は少なく, 周辺植生と緑化法面内一の種子散布量との 関係を明らかにすることは，遅速緑化や植生管理を考える上 で重要であると考えた。

そこで本研究では，植生管理の基礎データに資することを 目的に, シードトラップを用いて周辺植生と緑化法面内への 散布種子との関係を明らかにすることを試みた。

\section{2. 調查方法}

\section{1 調査地の概要}

調查地は, 静岡県沼津市井田の県道 17 号線（沼津一土肥 線）に面する道路法面 $\left(34^{\circ} 59^{\prime} \mathrm{N}, 138^{\circ} 46^{\prime} \mathrm{E}\right)$ (以下, 井田
法面と称す) で, 標高は $100 \sim 150 \mathrm{~m}$, 年平均気温は $15.3{ }^{\circ} \mathrm{C}$, 年平均降水量は $1,846.1 \mathrm{~mm}$, 年平均日照時間は 1912.1 時間 である。なお，気象データは静岡県三島における 1971 年か ら 2000 年までの気象庁の平年值である。

井田法面は, 施工後経過年数 14 年, 面積 $2,434 \mathrm{~m}^{2}$, 法長 $174.7 \mathrm{~m}$, 斜面の平均傾斜 $45^{\circ}$, 斜面方位 NW の切土法面で ある。調査は, 井田法面および法面上部に隣接する自然林 (以 下周辺林）において行った。導入樹種および緑化基盤材につ いての詳細は, 既報 9,10$)$ に記載されている。導入樹種のうち, 現在成立が認められたのはオオバヤシャブシのみである。

調査地を周辺林, 法面上部および法面下部の 3 つに分割し, さらにコンパス測量によりサブプロットとしてそれぞれを $10 \mathrm{~m} \times 10 \mathrm{~m}$ の方形区に 3 分割した。図-1にプロットを示寸。 2.2 毎木調查

調查地内における木本植物の組成を明らかにするために, 2009 年 9 月に毎木調査を行った。測定項目として周辺林, 法面上部，法面下部のそれぞれのプロットにおいて，種名，

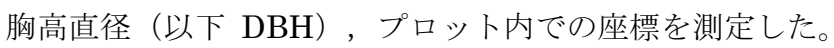
算出項目として DBH から胸高断面積を算出し, さらに樹種 ごとの胸高断面積合計（以下 BA）を計算し，相対優占度（以 下 RBA）を算出した。また，類似度を用いることは通常の群 落分類法の補助的手段として有用であると言われている5)た

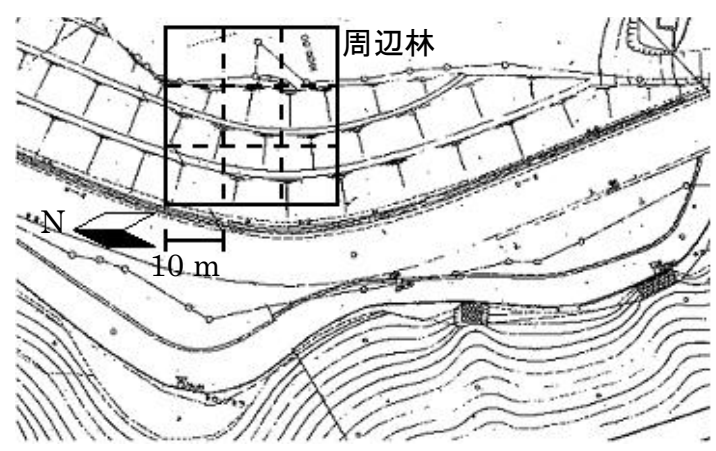

図-1プロットの設置場所

* 連絡先著者: E-mail : 63100003@nodai.ac.jp厂１56-8502 東京都世田谷区桜丘 1-1-1 
め, 成木にはRBAを，稚樹には個体数を用いて（1）式によ

り Bray-Curtis 類似度指数 ${ }^{7}$ を算出した。

$$
1-\delta_{A B}=\frac{\sum_{i=1}^{S}\left|n_{A i}-n_{B:}\right|}{N_{A}-N_{B}} \quad(0 \leqq \delta \mathrm{AB} \leqq 1)
$$

$\mathrm{N}_{\mathrm{Ai}}$ ：プロット $\mathrm{A}$ の $\mathrm{i}$ 番目の種の個体数（あるいは $\mathrm{RBA）}$

$\mathrm{N}_{\mathrm{A}}$ ：プロット $\mathrm{A} の$ 全個体数 $\mathrm{S}$ : 全種数 $\left(\mathrm{n}_{\mathrm{Bi}}, \mathrm{N}_{\mathrm{B}}\right.$ も同様 $)$

RBA および Bray-Curtis 類似度指数はオオバヤシャブシを 計算に含めたものと含めなかったものとの 2 通りを算出した。 なお, 本稿では, 樹高 $120 \mathrm{~cm}$ 以上で胸高直径が $3 \mathrm{~cm}$ 以上 のものを成木，それ以外のものを稚樹とした。

\section{3 シードトラップによる調査}

調査地内に散布される種子を把握するために, 2009 年 7 月末に $1 \mathrm{~mm}$ メッシュの寒冷紗製のシードトラップを各方形 区にそれぞれ 3 つずつ設置した（周辺林内 9 個，法面上部 9 個, 法面下部 9 個）。シードトラップは開口部面積 $0.5 \mathrm{~m}^{2}$, 深さ約 $70 \mathrm{~cm}$ の円錐状で, 開口部が地上から $1 \mathrm{~m}$ の高さに水 平になるように設置した。シードトラップの内容物を毎月研 究室に持ち帰り同定した。なお種子は 3 つの散布型に整理し

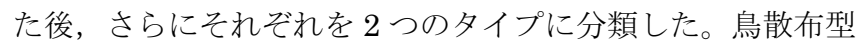
種子については果肉の付いている種子を自然落下種子, 付い ていないものを鳥散布種子とした。風散布種子および重力散

表-1 各斜面位置における樹種の断面積合計（BA）

\begin{tabular}{|c|c|c|c|c|c|}
\hline \multirow{2}{*}{\multicolumn{2}{|c|}{ 散布型種名 }} & \multirow[b]{2}{*}{ 学名 } & \multicolumn{3}{|c|}{ 胸高断面積合計 $\left(\mathrm{cm}^{2}\right)$} \\
\hline & & & 周边林 & 法面上部 & 法面下部 \\
\hline \multirow{15}{*}{ 鳥 } & ヒメユズリハ & Daphniphyllum teijsmannii Zoll. ex Kurz. & 2392.1 & & \\
\hline & ヤブニッケイ & Cinnamomum japonicum Sieb. ex Nakai & 1012.2 & 7.1 & 8.0 \\
\hline & ハゼノキ & Rhus succedane & 884.2 & 81.1 & 3308.9 \\
\hline & イヌマキ & Podocarpus macrophyllus (Thunb.) D. Don & 582.8 & & \\
\hline & カラスザンショ & Zanthoxylum ailanthoides Sieb. et Zucc. & 433.0 & & \\
\hline & シキミ & Illicium anisatum $\mathrm{L}$. & 415.5 & & \\
\hline & シロダモ & Neolitsea sericea (BL.) Koidz. & 318.1 & & \\
\hline & ヒサカキ & Euryaja & 289.6 & 37.7 & \\
\hline & エゴノキ & Styrax ja & 120.6 & & 13.4 \\
\hline & キブシ & Stachy & 56.7 & 59.7 & 67.9 \\
\hline & イヌガシ & Neolitse & 22.2 & & \\
\hline & アカメガシワ & Mallotus japonicus (Thunb.) Muell.Arg. & 19.6 & & 38.5 \\
\hline & オオシマザクラ & Prunus lannesiana & & 46.8 & 121.0 \\
\hline & サカキ & Cleyeraja & & 19.6 & \\
\hline & ガマズミ & Viburnum dilatum Thunb. & & 7.1 & \\
\hline \multicolumn{3}{|c|}{ 各斜面位置にお计る鳥散布型樹木の胸高断面積合計 } & 6546.5 & 259.1 & 3557.7 \\
\hline \multirow{3}{*}{\multicolumn{2}{|c|}{ 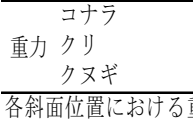 }} & Quercu & 2384.9 & 195.8 & 100.1 \\
\hline & & Castanea crenata Sieb. et Zucc. & & 24.1 & \\
\hline & \multicolumn{2}{|c|}{ 各斜面位置における重力散布型樹木の胸高断面積合計 } & 2384.9 & 219.9 & 153.9 \\
\hline \multirow{3}{*}{ 風 } & ヒメシャラ & Stewartic & 241.5 & 171.2 & 17.9 \\
\hline & クロマツ & Pinus densiflora Sieb. et Zucc. & 165.1 & 81.3 & 262.0 \\
\hline & オオバヤシヤブシ & Alnus sieboldiana matsum. & & 1799.2 & 3381.7 \\
\hline \multirow{2}{*}{\multicolumn{3}{|c|}{ 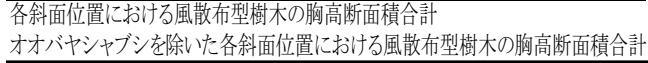 }} & 406.6 & 2051.7 & 3661.7 \\
\hline & & & 406.6 & 252.5 & 280.0 \\
\hline \multirow{2}{*}{\multicolumn{3}{|c|}{ 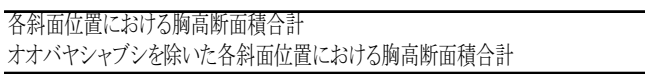 }} & 9338.0 & 2530.7 & 7373.3 \\
\hline & & & 9338.0 & 731.5 & 3991.6 \\
\hline
\end{tabular}

※*は導入樹種を表す。
布種子は, 著しくサイズの小さいものや久けているものは未 熟種子, それ以外を自然落下種子とした。シードトラップに よる調査期間は 2009 年 8 月〜 2010 年 1 月までとした。なお, 導入植物であるオオバヤシャブシは散布種子から除外した。

\section{3. 結果}

\section{1 調查地の植生}

各樹種の BA を表- 1 に示し, 各斜面位置における上位 3 種 の RBA を図-2 に示す。各斜面位置において BA が大きかっ た上位 3 種について整理した。まず周辺林内においては，ヒ メユズリ八 $\left(2,392.1 \mathrm{~cm}^{2}\right)$, コナラ $\left(2,384.9 \mathrm{~cm}^{2}\right)$, ヤブ ニッケイ $\left(1,012.2 \mathrm{~cm}^{2}\right)$ となり，それぞれの RBA は 0.26, 0.26, 0.11 となった。次に法面上部においては, オオバヤシ ヤブシ $\left(1,799.2 \mathrm{~cm}^{2}\right)$ ，コナラ $\left(195.8 \mathrm{~cm}^{2}\right)$ ，ヒメシャラ $\left(171.2 \mathrm{~cm}^{2}\right)$ であった。それぞれの RBA は 0.71, 0.08, 0.07 となった。法面下部においては，オオバヤシャブシ $(3,381.7$ $\left.\mathrm{cm}^{2}\right)$ ，八ゼノキ $\left(3,308.9 \mathrm{~cm}^{2}\right)$, クロマツ $\left(262.0 \mathrm{~cm}^{2}\right)$ となり，それぞれの RBA は 0.46, $0.45 ， 0.04$ となった。導 入樹種であるオオバヤシャブシを除いた上位 3 種は, 法面上 部においてはコナラ, ヒメシャラ, クロマツ $\left(81.3 \mathrm{~cm}^{2}\right)$, RBA はそれぞれ $0.26,0.23,0.11$ となり, 法面下部におい てはハゼノキ, クロマツ, オオシマザクラ $\left(121.0 \mathrm{~cm}^{2}\right)$, RBA はそれぞれ 0.83，0.07，0.03 となった。法面上部と法 面下部との間において種組成は大きく変わらないが，優占す る種は異なった。

種子の散布型についてオオバヤシャブシを除いて整理する と, まず周辺林においては, 鳥散布型木本が $6,546.5 \mathrm{~cm}^{2}(※$ 各斜面位置における散布型の割合は $70 \%$ ）と最も多く, 次い

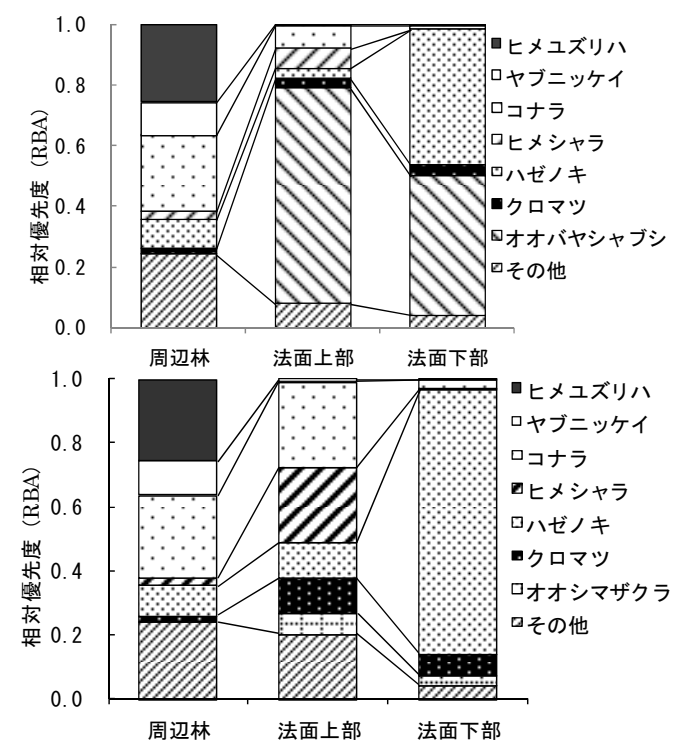

(a)

(b)

図-2 各斜面位置における上位 3 樹種の相対優先度（RBA） ※（a）オオバヤシャブシを含む

（b）オオバヤシャブシを除外 
で重力散布型木本が $2,384.9 \mathrm{~cm}^{2}$ (同， $26 \%$ ), そして風散 布型木本が $406.6 \mathrm{~cm}^{2}$ (同，4\%) となった。次に法面上部に おいては，鳥散布型木本が $259.1 \mathrm{~cm}^{2}$ (同，35\%）と最も多 く, 次いで風散布型木本が $252.5 \mathrm{~cm}^{2}$ (同, $35 \%$ ), そして 重力散布型木本が $219.9 \mathrm{~cm}^{2}$ (同, 30\%) となった。法面下 部においても，鳥散布型本が $3,557.7 \mathrm{~cm}^{2}$ (同, 89\%) と最 も多く, 次いで風散布型木本が $280.0 \mathrm{~cm}^{2}$ (同, $4 \%$ ）, そし て重力散布型木本が $219.9 \mathrm{~cm}^{2}$ (同，7\%）であった。以上の ように，全てのプロットにおいて鳥散布型木本が優占してい た。

異なる斜面位置間の Bray-Curtis 類似度指数を図-3 に示 す。なお，オオバヤシャブシの実生は確認されなかった。ま ず，成木について周辺林と法面上部および法面下部との間の 類似度を比較すると, Bray-Curtis 類似度指数は法面上部が 0.18 (オオバヤシャブシを除くと 0.53），法面下部が 0.14 (同, 0.37) となり, 法面下部よりも法面上部の方が 0.04 (同, 0.16）高かった。次に, 稚樹について比較すると, 法面上部 が 0.53 , 法面下部が 0.25 となり, 法面下部よりも法面上部 の方が 0.28 高かった。

\section{2 種子散布量}

各プロットに落下した種子数を表- 2 に示す。なお, 調查期間 中に法面において種子生産を行っていたのは八ゼノキだけで あった。周辺林を含む調査区内における散布種子数は 2,393 個であり，鳥散布型が 1,577 個, 重力散布型が 9 個, 風散布 型が 807 個であった。最も散布量が多かったのは周辺林 1,942 個であり，次いで法面上部が 806 個，法面下部は 182

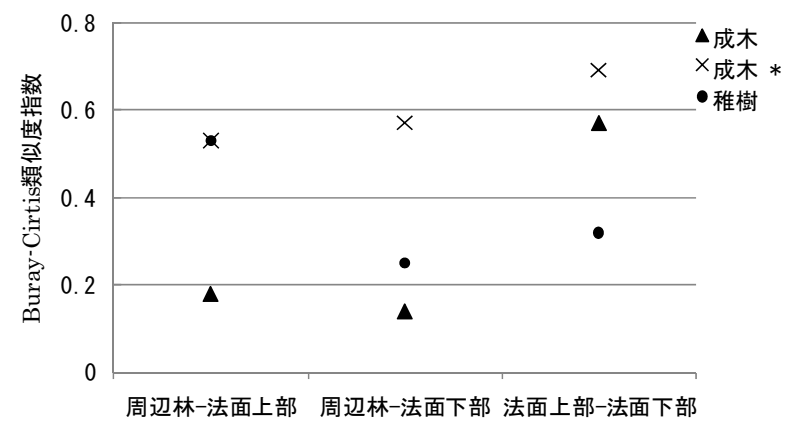

図-3 Bray-Curtis 類似度指数

※*はオオバヤシャブシを除外して計算した。

表-2 各斜面位置における散布種子の組成

\begin{tabular}{|c|c|c|c|c|c|c|c|c|c|c|}
\hline \multirow{2}{*}{ 散布型 } & \multirow[b]{2}{*}{ 種名 } & \multirow[b]{2}{*}{ 学名 } & \multicolumn{2}{|c|}{ 周辺林 } & \multicolumn{2}{|c|}{ 法面上部 } & \multicolumn{2}{|c|}{ 法面下部 } & \multicolumn{2}{|c|}{ total } \\
\hline & & & 自然 & 鳥 & 自然 & 鳥 & 自然 & 鳥 & 自然 & 鳥 \\
\hline \multirow{21}{*}{ 鳥 } & アカメガシワ* & Mallotus japonicus (Thunb.) Muell. Arg. & 22 & 114 & 1 & 18 & & 6 & 23 & 138 \\
\hline & イヌビワ & Ficus erecta Thunb. & 1 & 22 & & 4 & 9 & 10 & 10 & 36 \\
\hline & イヌマキ* & Podocarpus macrophyllus (Thunb.) D. Don & 30 & & 2 & 2 & & & 32 & 2 \\
\hline & エゴノキ* & Styrax japonica Sieb. et Zucc. & & 1 & & & & & & 1 \\
\hline & エノキ & Celtis sinensis Persoon var. japonica (Planch.) Naka & & 7 & & 1 & & 1 & & 9 \\
\hline & カラスザンショウ* & Zanthoxylum ailanthoides Sieb. et Zucc. & 159 & 319 & 6 & 239 & 1 & 28 & 166 & 586 \\
\hline & クスノキ & Cinnamomum camphora (L.) Presl & & 5 & 1 & 1 & & & 1 & 6 \\
\hline & クマノミズキ & Swida macrophylla (Wall.) Soj. & 2 & 44 & & 26 & & 7 & 2 & 77 \\
\hline & シキミ* & Illicium anisatum $\mathrm{L}$. & (1) & & & 1 & & & (1) & 1 \\
\hline & トベラ & Pittosporum tobira (Thunb. ex Murray) Aiton & & 1 & & 1 & & 1 & & 3 \\
\hline & ハゼノキ* & Rhus succedanea L. & 17 & 9 & 1 & 4 & 80 & 25 & 98 & 38 \\
\hline & ヒイラギ & Osmanthus heterophyllus (G. Don) P. S. Green & & 1 & & & & & & 1 \\
\hline & ヒサカキ* & Eurya japonica Thunb. & 421 & 99 & 141 & 114 & & 8 & 25 & 221 \\
\hline & ヒメユズリハ* & Daphniphyllum teijsmannii Zoll. ex Kurz. & 16 & 6 & 18 & 2 & & & 34 & 8 \\
\hline & ムラサキシキブ & Callicarpa japonica Thunb. & & 8 & 1 & 6 & & & 1 & 14 \\
\hline & ヤブニッケイ* & Cinnamomum japonicum Sieb. ex Nakai & & 13 & & & & 1 & & 14 \\
\hline & ヤブムラサキ* & Callicarpa mollis Sieb. et Zucc. & & 9 & 5 & 14 & & & 5 & 23 \\
\hline & ヤマグワ & Morus australis Poiret & & & & 1 & & 1 & & 2 \\
\hline & No. of seeds & & 668 & 658 & 176 & 434 & 90 & 88 & 397 & 1180 \\
\hline & No. of species & & 8 & 16 & 9 & 15 & 3 & 10 & 12 & 18 \\
\hline & & & \multicolumn{2}{|c|}{ 周辺林 } & \multicolumn{2}{|c|}{ 法面上部 } & \multicolumn{2}{|c|}{ 法面下部 } & \multicolumn{2}{|c|}{ total } \\
\hline 散布型 & 種名 & 学名 & 自然 & 熟 & 自然 & 未熟 & 自然 & 未熟 & 自然 & 未熟 \\
\hline \multirow{4}{*}{ 重力 } & コナラ* & Quercus serrata Thunb. ex. Muuray & & 4 & & 4 & & & 0 & 8 \\
\hline & クリ & Castanea crenata Sieb. et Zucc. & & & 1 & & & & 1 & 0 \\
\hline & No. of seeds & & 0 & 4 & 1 & 4 & 0 & 0 & 1 & 8 \\
\hline & No. of species & & 0 & 1 & 1 & 1 & 0 & 0 & 1 & 1 \\
\hline & & & 周边 & & 法面 & 上部 & 法面 & 下部 & to & \\
\hline 散布型 & 種名 & 学名 & 自然 & 熟 & 自然 & 未熟 & 自然 & 未熟 & 自然 & 未熟 \\
\hline \multirow{6}{*}{ 風 } & クロマツ* & Pinus thunvergii $\quad$ Parlatore & & & 1 & 1 & & & 1 & 1 \\
\hline & ヒメシャラ* & Stewartia monadelpha Sieb. et Zucc. & 601 & 11 & 186 & 3 & 2 & 2 & 789 & 16 \\
\hline & No. of seeds & & 601 & 11 & 187 & 4 & 2 & 2 & 790 & $\overline{17}$ \\
\hline & No. of species & & 1 & 1 & 2 & 2 & 1 & 1 & 2 & 2 \\
\hline & Total No. of seeds & & 1269 & 673 & 364 & 442 & 92 & 90 & 1188 & 1205 \\
\hline & Total No. of species & & 9 & 18 & 12 & 18 & 4 & 11 & 15 & 21 \\
\hline
\end{tabular}

鳥:鳥に散布されたと思われる種子を表す。自然:自然に落下した種子を表す。未熟未熟と思われる種子および、破損していた種子を表す。

值は 9 トラップの合計值を表す。*は周辺林に確認された種を表す。括弧内は果実の数を表す。 
個となった。なお，法面下部は周辺林に比べて種子数が有意 に少なかった（Tukey-test : $p<0.05$, 以下同様）。

種数は 22 種で, 散布型による内訳は鳥散布型が 18 種, 重 力散布型が 2 種, 風散布型が 2 種であり鳥散布型種子が占め る種数の割合は約 $82 \%$ \%あった。このときの散布種子種数は 周辺林 19 種, 法面上部 19 種, 法面下部 11 種となり, 法面 下部が最も少なかった。なお, 種子の供給源が不明の種は, イヌビワ, エノキ, クマノミズキ, ヒイラギ, ヤマグワであ った。逆に, 結実を確認したが種子を捕捉することができな かった種は, シロダモ, キブシ, タブノキであった。各プロ ットの鳥散布型種子の散布種子種数を図-4 に示す。鳥散布型 種子 1,577 個の内，鳥散布種子が 1,180 個, 自然落下種子が 397 個であり，鳥散布型種子において鳥散布種子が $74.8 \%$ を 占めた。同一の斜面位置内における鳥散布型種子の種子数に ついて, 自然落下種子と鳥散布種子との間に有意な差が見ら れた。なお, 異なる斜面位置間の自然落下種子数は, 周辺林法面上部および周辺林-法面下部において有意な差は見られ なかったが, 鳥散布種子数および鳥散布種子の種数は周辺林 と比較して法面下部が有意に低い值となった。

\section{4. 考察}

各条件間における BA を比較すると, 法面上部が $2,530.7$ （オオバヤシャブシを除くと 731.5） $\mathrm{cm}^{2}$ であり，法面下部 は7373.3（同 3,991.6） $\mathrm{cm}^{2}$ となった。既存の研究 5) どおり, 植物バイオマスを指標とする遷移は, 法面下部の方が進んで いると考えられる。特に法面下部における八ゼノキの RBA はオオバヤシャブシと同程度であり, 他の侵入植物よりも高 い值を示していた。また，法面下部における単位面積当たり の数は法面上部の 8.5 倍であり, 単木当たりの BA は 4.8 倍 であった。なお, 八ゼノキの分布は集中しており, これは緑 化施工後初期に侵入したためであると緑化樹木と競合するこ とが少なかったためであると思われる。

次に Bray-Curtis 類似度指数の結果では, 成木, 稚樹のど ちらの值も法面上部の方が法面下部よりも周辺林との類似度 が高かった。また, 散布種子数および種数は周辺林から離れ るほど減少し, 特に風散布型のヒメシャラは, 法面上部と法 面下部とを比較するとオーダー単位の差が認められた。この ことから, 法長を長くすると法面下部において植物の侵入が 遅れることが示唆された。

\section{5. おわりに}

今回の調査では, 周辺植生を法肩に接する自然林としたが, 植生調査の際に見られなかった樹種の種子が捕捉された。し かし, 出現種数は調査範囲を広げるほど多くなると予想され るが，労力とのバランスがとれる調査区設定を考えていく必 要がある。

今後, 自然回復緑化等で周辺からの種子散布を考える際,

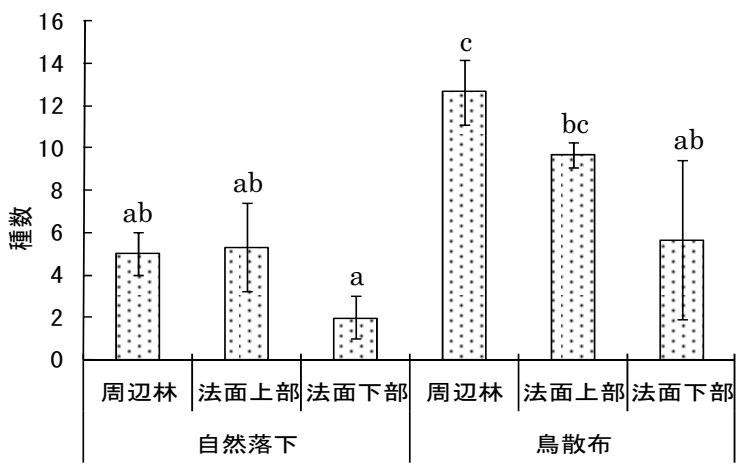

図-4 各斜面位置における鳥散布型種子の散布種子種数 ※エラーバーは標準偏差を示す。異なるアルファベット間におい て有意差が認められたことを示す（Tukey-test : $p<0.05 ） 。$

樹木の種子生産は豊凶があるため, 今後も長期的な調査が望 まれる。また，樹種ごとの種子散布距離や種子散布パターン を明らかにすることで，侵入植物をより正確に推定すること ができると考えられる。

\section{引用文献}

1）樋口高志・肥後睦輝（1994）伐採跡地における落下種子の 種組成，岐阜大農研報（59）：1-10.

2）平田令子・畑邦彦・曽根晃一（2006）果実食性鳥類による 針葉樹人工林への種子散布, 日本林学会誌, 88 (6) : 515-524.

3）星子 隆（1999）高速道路法面における木本植物の侵入と 種子散布様式に関する研究, 日本緑化工学会誌, 25（2） : 102-114.

4) 星子 隆・吉田裕介（2000）第二東名高速道路切土のり面 への木本植物侵入予測に関寸る研究, 日本緑化工学会誌, 25 (4) : 367-372.

5）亀山 章 (1978), 高速道路のり面の植生遷移について (II) - 群落調査による遷移の診断と遷移系列の推定 - , 造園雑 誌 (41) : 2-15.

6) 日本緑化工学会（2002）生物多様性保全のための緑化植物 の取り扱い方に関する提言，日本緑化工学会誌，27（3） : 482-491.

7) 大垣俊一 (2008) 多様度と類似度, 分類学的新指標, Argonauta (15) : 10-22.

8）佐藤 創（1988）樹冠下のかき起しによる多様な樹種の更 新 ( I ) 一種子散布から実生定着までの過程一, 北海道林 業試験場研究報告, $35: 21-30$.

9）橘 隆一・今井基裕・福永健司（2002）緑化法面における 土壤微生物相の変化, 日本緑化工学会誌 28 (1) : 224-227.

10）橘 隆一・西村加奈子・宮本沙織・福永健司（2003）アリ 類とトビムシ類の群構成による緑化法面の環境指標, 日本 緑化工学会, 29 (1) : 56-61.

11）吉田 寬（2000）厚層基材吹付工施工後の植生遷移に関寸 る研究, 日本緑化工学会誌, 25 (4) : 305-310.

(2010. 7. 24 受理) 